\title{
ANALYSIS OF POSSIBILITIES FOR IMPROVING ENTREPRENEURIAL BEHAVIOUR OF YOUNG PEOPLE - RESEARCH RESULTS IN CENTRAL BANAT DISTRICT
}

\author{
UDC: 005.961:005.914.3-053.81(497.113 Banat) \\ Original Scientific Paper Edit TEREK ${ }^{2}$
${ }^{1}$ University of Novi Sad, Technical faculty "Mihajlo Pupin” Zrenjanin, 23000 Zrenjanin, Đure Đakovića bb, Republic of Serbia
E-mail: dragan.cockalo@tfzr.rs
${ }^{2}$ University of Novi Sad, Technical faculty “Mihajlo Pupin” Zrenjanin, 23000 Zrenjanin, Đure Đakovića bb, Republic of Serbia \\ Dragan ĆOĆKALO ${ }^{1}$, Dejan ĐORĐEVIĆ ${ }^{2}$, Milan NIKOLIĆ ${ }^{2}$, Sanja STANISAVLJEV ${ }^{2}$,
}

Paper received: 20.11.2017; Paper accepted: 18.12.2017.

\begin{abstract}
Unemployment, especially among young population, represents one of key economic problems. All important institutions have to be included in overcoming these problems, with the aim of stimulating young people to be involved in entrepreneurial processes. In this paper, global and European trends and trends in the Western Balkans are shown, related to unemployment of young population (aged 15-24). The central part is dedicated to the analysis of possibilities for improving entrepreneurial behaviour of young people in the Central Banat District, on the basis of trends, statistical indicators and the results of conducted research on attitudes of young people towards entrepreneurship and starting their own business. The research sample conducted in 2016 consisted of 350 respondents. The young are often unmotivated to get involved in entrepreneurial processes they wish to start their own business, but most frequently claim to be distracted by: lack of funds, lack of experience in running a company, lack of knowledge, as well as lack of the right idea. Factors, which distract respondents from starting their own business, represent the result of nonexisting adequate environment for supporting young entrepreneurship.
\end{abstract}

Keywords: Unemployment, Entrepreneurship, Young as entrepreneurs, Self-employment, Regional development.

\section{INTRODUCTION}

The development of entrepreneurial behaviour among the young is a complex area, but essentially comes down to several factors which together comprise a suitable environment for encouraging them. Special attention is paid to the acquisition of knowledge in the field of entrepreneurship among young people, with the aim of their professional development. There are a lot of previous studies dealing with motivation (for example Abbey (2002), etc.), intentions (for example Thompson (2009), etc.) - elements that influence developing entrepreneurial behavior and starting business in different ways (for example McKenzie et al. (2007), Wilson et al. (2007), Franco et al. (2010) etc.), in other words, progressive behavior of young people.

\section{YOUTH UNEMPLOYMENT RATE TRENDS}

\section{Regional trends $^{1}$}

Between 2007 and 2010, after fast growth rate period, global youth unemployment rate remained constant at $13 \%$ for the period from 2012 to 2014 . The number of unemployed people decreased by 3.3 million at the peak of crisis: 76.6 million of young people were unemployed in 2009 compared to estimated 73.3 million in 2014.

\footnotetext{
${ }^{1}$ Based on the ILO (2015) data.
} 
The share of young people in total unemployment is slowly decreasing. In 2014, 36.7\% of young people were unemployed globally. Ten years earlier, in 2004, the share of youth in total unemployment was $41.5 \%$. Although, over time, the indicator showed an improvement, it should be noted that in 2014, young people made up only one-sixth of the world's population and that's why they are overrepresented among the unemployed, (UN, 2014).

In 2014, youth unemployment was the highest in the Middle East and North Africa at $28.2 \%$ and $30.5 \%$, and the lowest in South Asia (9.9\%) and East Asia (10.6\%).

The situation with youth unemployment in developed economies and in the European Union, the region that was most affected during the crisis, began to decline as of 2012. The youth unemployment rate decreased between 2012 and 2014 and declined from $18 \%$ to $16.6 \%$ and it is expected that the reduction trend will continue to the projected $15.1 \%$ in 2020 .

Recovery has yet to ensue in many European countries. In 2014, the unemployment rate for young people exceeded 20 percent in two thirds of European countries.

Between 2012 and 2014, the youth unemployment rate decreased in: Central and Southeastern Europe (non-EU countries) and the CIS (from 17.4\% to 17.2\%), Latin America and the Caribbean (from $13.5 \%$ to $13.4 \%$ ) and sub-Saharan Africa (from 12.1 to $11.6 \%)$. The rate increased in this period in East Asia (from 10.1 to $10.6 \%$ ), in the Middle East (from 27.6 to 28.2\%), North Africa (from 29.7 to $30.5 \%$ ) and Southeast Asia and the Pacific (from 12.7 to $13.6 \%$ ). There was no change of rate in South Asia.

Gender differences are small at a global level, as in most regions related to the unemployment rate among young people. In the Middle East and North Africa, however, the unemployment rate for young women exceeds the number of young men from as much as $22 \%$ and $20 \%$, respectively.

In 2014, the total youth unemployment rate in high-income countries was $6.5 \%$ higher than in low-income countries (16.1 and 9.6\%). However, the youth unemployment rate has almost doubled in the low income group when an informal definition of unemployment is being implemented.
The youth unemployment rate is increasing in line with the level of education that has been achieved in Asia and the Pacific, the Middle East, and North Africa and sub-Saharan Africa. The number of unemployed young people who completed higher education in these three regions was two to three times higher than those who completed primary education or were not even educated. In higher income regions, young people with lower education are more confronted with challenges of finding a job.

The share of the youth population that is neither employed nor in education or training (NEET's rate) peaked in 2010 at the height of the Great Recession in the majority of developed economies (2012 in the European Union). Participation of young NEETs in the European Union (EU-28) began to decline from the peak of $13.1 \%$ in 2012 to $12.4 \%$ in 2014 .

In the European Union (28 countries), more than one in three $(35.5 \%)$ of unemployed youth sought work for more than one year in 2014, which is an increase of $32.6 \%$ in 2012.

Long-term unemployment is also a problem among low income countries. The long-term youth unemployment rate in Sub-Saharan Africa was $48.1 \%$, followed by the Middle East and North Africa (60.6\%). Looking at the income level, there is a somewhat higher likelihood of long-term unemployment in low-income countries in comparison with countries with higher and middle income ( $43.4 \%$ and $40.9 \%$, respectively).

The ILO study on mechanisms for coordination of youth employment in East Africa (Phororo, 2013) pointed out that the design and implementation approaches that have proven to be effective include: (1) integrating youth employment into a wider national plan and development strategy, but with explicit goals; (2) a clear indication of the role and responsibilities of different implementation partners in employment policies and action plans for youth employment; (3) establishing links between youth employment policies and other policies resulting in the employment of young people; (4) a reflection of the government's obligation to employ young people in national budgets; and (5) the establishment of monitoring and evaluation mechanisms, not only for programs, but also for budgetary allocations for the employment of young people. 


\section{Europe and the Western Balkans region}

The total unemployment rate (with regard to the active population, 15-74 years) for EU countries (28 countries) ranges from $10.8 \%$ in 2013 , when it was the highest for the observed period 2010-2016, to $8.6 \%$ in 2016. However, there are large variations between Member States, with the highest unemployment rate for young people in the southern and peripheral countries of the EU whose labor markets are most affected by the severe recession. Norway has the lowest average unemployment rate $(3.6 \%)$, followed by Switzerland and Iceland with $4.8 \%$ of total unemployment, Germany (5.3\%) and UK (6.8\%). The lowest unemployment rate in the EU (28 countries) in 2016 is in Iceland (3\%), then Czech Republic (4.0\%), followed by aforementioned Germany (4.1\%), Norway (4.7\%) and UK (4.8\%), then Malta (4.7\%), Switzerland (5\%) and Hungary (5.1\%), which is also the best placed neighboring country of Serbia. Greece and Spain have the highest average rate of total unemployment in the period from 2010-2016 - approximately the same rate of $22.6 \%$, followed by Portugal (13.5\%), Cyprus with $12.3 \%$ and Italy with $10.8 \%$ of total unemployment. These countries are also among the highest when it comes to total unemployment in the EU (28 countries) in 2016 . The country with the lowest unemployment rate in the area of Western Balkans is Slovenia, with an average unemployment rate of $8.7 \%$, and total unemployment rate of $8 \%$ in 2016 . In addition to Greece from the EU (28 countries) from the Balkans, Croatia is leading average with the total average rate of $15.1 \%$ in the observed period and unemployment of $13.1 \%$ in 2016.

Table 1 shows the unemployment rate among young people (15 to 24) in some European countries in different periods from 2010 to 2016. What can be immediately noticed is that there is a big difference in the percentage of unemployment among young people in the observed period. In some countries like Greece, the rate is increased by almost $77 \%$ of the lowest value. In Estonia, the unemployment rate of this population has been reduced by almost 2.5 times in 2016 compared with the beginning of the observed period. The most stable unemployment rate for the young population in the observed period is maintained by Germany and France - the first at a low average level of $8.0 \%$, and the other at a relatively high $23.8 \%$. Spain is a country that had the highest overall youth unemployment rate of $49.3 \%$ in the observed period and, in absolute terms, is also a notorious record holder.

Table 1: Youth unemployment rate(15-24) (in percentage)

\begin{tabular}{|l|c|c|c|c|c|c|c|}
\hline Country & 2010 & 2011 & 2012 & 2013 & 2014 & 2015 & 2016 \\
\hline EU $(28$ countries $)$ & 21.0 & 21.7 & 23.2 & 23.6 & 22.2 & 20.3 & 18.7 \\
\hline France & 22.5 & 21.9 & 23.7 & 24.1 & 24.2 & 24.7 & 24.6 \\
\hline Germany & 9.8 & 8.5 & 8.0 & 7.8 & 7.7 & 7.2 & 7.1 \\
\hline Greece & 33.0 & 44.7 & 55.3 & 58.3 & 52.4 & 49.8 & 47.3 \\
\hline Hungary & 26.4 & 26.0 & 28.2 & 26.6 & 20.4 & 17.3 & 12.9 \\
\hline Italy & 27.9 & 29.2 & 35.3 & 40.0 & 42.7 & 40.3 & 37.8 \\
\hline Poland & 23.7 & 25.8 & 26.5 & 27.3 & 23.9 & 20.8 & 17.7 \\
\hline Slovakia & 33.6 & 33.4 & 34.0 & 33.7 & 29.7 & 26.5 & 22.2 \\
\hline Spain & 41.5 & 46.2 & 52.9 & 55.5 & 53.2 & 48.3 & 44.4 \\
\hline United Kingdom & 19.9 & 21.3 & 21.2 & 20.7 & 17.0 & 14.6 & 13.0 \\
\hline Estonia & 32.9 & 22.4 & 20.9 & 18.7 & 15.0 & 13.1 & 13.4 \\
\hline
\end{tabular}

An increasing number of unemployed young people represent a significant loss of human capital that could otherwise contribute to economic growth. It is estimated that the economic loss due to unemployment of young NEETs amounts to approximately 162 billion Euros, which corresponds to about $1.25 \%$ of the European gross domestic product (GDP), (Eurofound, 2014). Being unemployed at a young age may also have long-term negative effects in terms of, for example, subsequent lower wages, reduced employment prospects and a lower level of wellbeing (see Bell \& Blanchflower (2011) and Strandh et al. (2014)).

Contrary to this, entrepreneurship among young people is increasingly seen as a creation of a policy of sustainability to address youth unemployment, promoting job creation and helping young people to discover their entrepreneurial potentials and 
talents. Entrepreneurship among young people is not only viewed as a possible way out of unemployment, but also as an alternative to traditional forms of employment that are becoming less common in the current economic climate. It is also a potential source of economic dynamics and the positive effects of secondary employment if sustainable companies are set up.

Starting a new job, however, is not a risk-free choice for young entrepreneurs but it is in itself a solution to the youth unemployment problem. The previous survey pointed to the similarities and differences between entrepreneurship among young people and entrepreneurship in general. According to the International Labor Organization (ILO) research, young people face unique constraints and greater entrepreneurial challenges compared to older age groups due to limited resources and experiences. The report emphasizes that "the scope of barriers, as well as the variety of potential methods and measures for their opposition, are more extensive than for older entrepreneurs" (Schoof, 2006).

Among the most prominent obstacles are lack of capital and insufficient funds for initial financing, lack of business experience and skills related to business management, limited experience in administration and procedures, lack of business connections and limited knowledge of available business support services. Negative social and cultural attitudes towards youth entrepreneurship, which differ between countries, can also act as a powerful impediment by creating fears of failure and thus potentially stop young people from making a breakthrough and starting a new job.

The overall unemployment rate (relative to the active population, 15-74 years) for the countries of the Western Balkans is extremely high - Figure 1 The most favorable to the European average, where the total unemployment rate for the observed period was between $8.6 \%$ and $10.8 \%$, is Slovenia. The total unemployment rate in Serbia has been significantly reduced compared to 2012 and in 2016 it amounts to $15.3 \%$. The highest overall unemployment rate in the region, in the observed period, is recorded in Bosnia and Herzegovina (more or less on a permanent level) and Macedonia, which records a fall in the unemployment rate in the observed period.

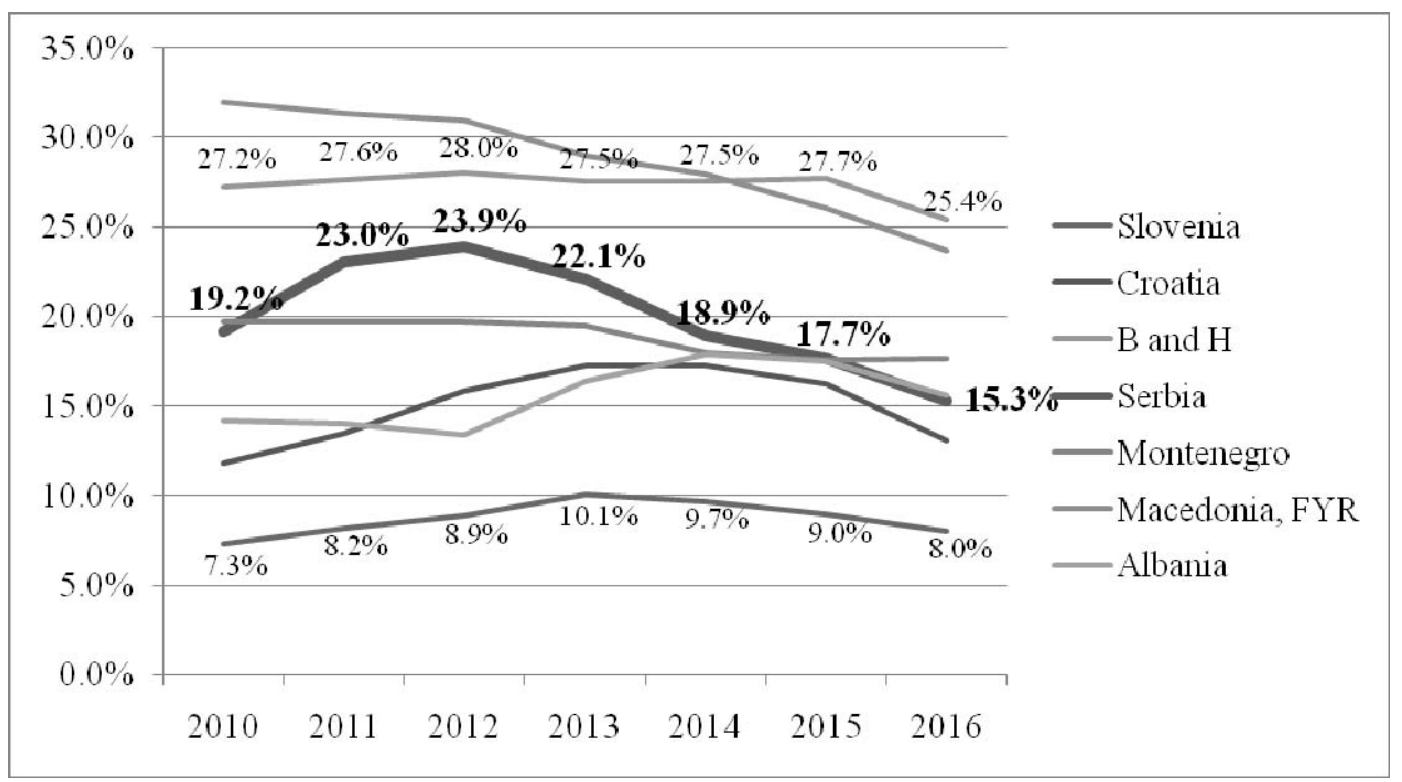

Figure 1: The total unemployment rate (with regard to the active population) for the countries of the Western Balkans, in the period 2010-2016.

Source: SORS, 2017.

The young population (15-24) is the least active age category - the activity rate in Serbia is between $27.7 \%$ from 2010 to 2016 and has a tendency of growth to $30.3 \%$. In Vojvodina, the activity rate among the young population is higher, in the observed period it ranges between $28.9 \%$ and $34 \%$, with a constant growth trend. Unemployment rate in relation to the active part of the population among this population does not go below 34.9\% for Serbia and $35.1 \%$ for Vojvodina. Figure 2 
shows the unemployment rate of the young age population for the countries of the Western population (15-24) in relation to the total active

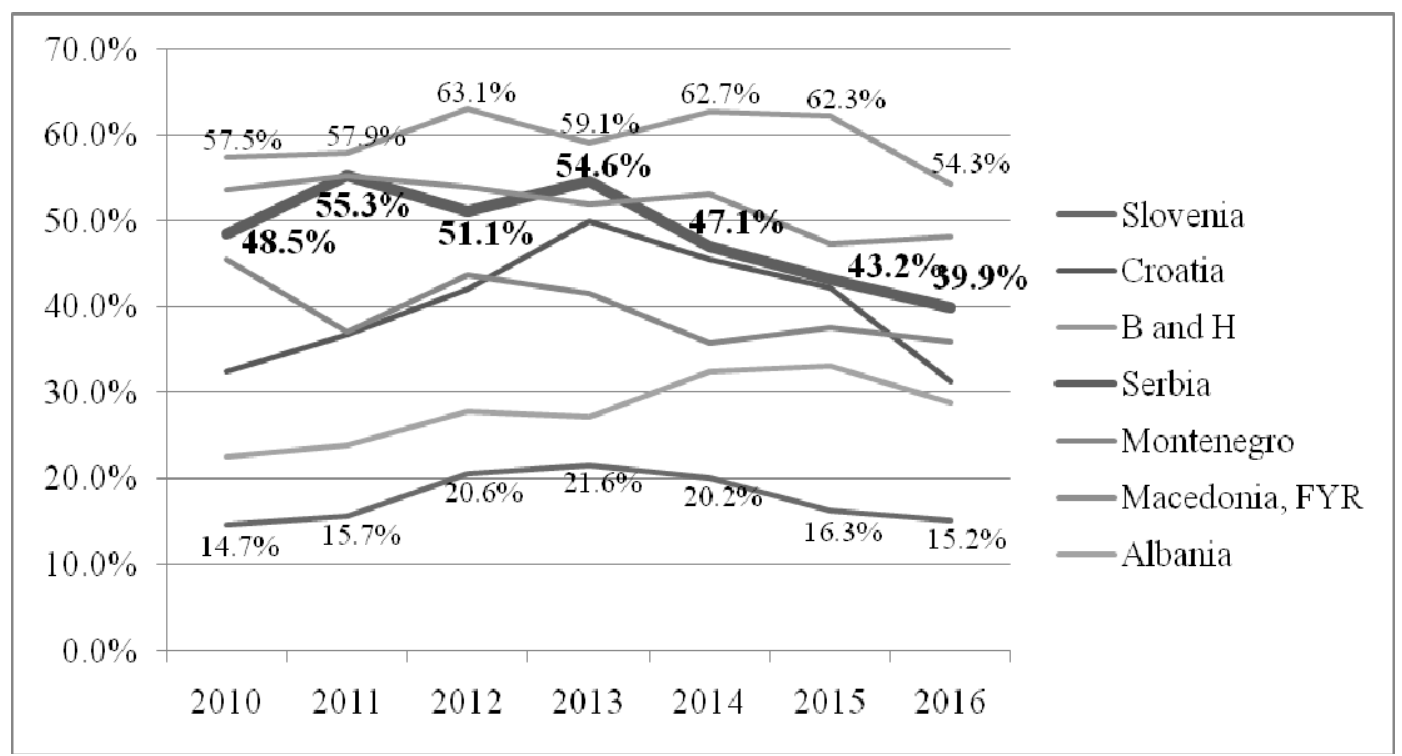

Figure 2: Unemployment rate for the young population (15-24) compared with the total working-age population for the countries of the Western Balkans; the period from 2010-2016

Source: SORS, 2017.

\section{Attitudes towards self-employment}

A special report focusing on youth entrepreneurship, which relies on the Global Entrepreneurship Monitoring (GEM) data from 2013, shows that in the EU (compared with other areas around the world) younger populations (aged 18-34) as well as the elderly (aged 35-64), have a fear of failure and that prevents them from starting their business to the greatest extent- $46.7 \%$ of them expressed this opinion (Eurofound, 2016; Kew et al., 2013). The OECD and the European Commission's joint research highlighted the various barriers that could affect the rate of young entrepreneurship, including models and attitudes, entrepreneurial skills and experience, financial resources and market barriers (European Commission, 2014).

The latest Flash Eurobarometer on Entrepreneurship shows that young people (between 15-24 years old) most often point out the lack of necessary skills as one of the main reasons why they do not start their own business, while those aged 25 to 39 will most often mention the lack of capital and financial resources for selfemployment (Table 2).

Table 2: Biggest limitations to self-employment in observed age groups (in \%)

\begin{tabular}{|l|c|c|c|c|}
\hline & $15-24$ & $25-39$ & $40-54$ & $55+$ years \\
\hline Not enough capital & 26 & 35 & 27 & 10 \\
\hline Current economic climate is not good for a start-up & 12 & 16 & 15 & 8 \\
\hline Not enough skills to be self-employed & 18 & 9 & 7 & 5 \\
\hline No business idea & 8 & 11 & 9 & 4 \\
\hline Difficult to reconcile with family commitments & 4 & 9 & 7 & 6 \\
\hline Risk of failure and legal and social consequences are too big & 3 & 8 & 7 & 3 \\
\hline
\end{tabular}

Source: European Commission, 2012

Despite numerous obstacles to entrepreneurship, there is evidence that perceptions of entrepreneurship are particularly positive among young people. Data Eurobarometer shows a greater inclination of young people to engage in entrepreneurial activities, (European Commission,
2012). Young people aged $15-24$ (45\%) in the EU are more inclined to self-employment than the older age groups (between $37 \%$ and $35 \%$ ). The younger age groups (15-24 and 25-39 years) also express a higher level of confidence that selfemployment would be feasible for them $(41 \%$ and 
$44 \%$ respectively) over the next five years. Figures were lower among older respondents aged 40-54 $(33 \%)$ and over 55 years old $(16 \%)$.

\section{Young "Call for action"}

Growing amid rapid technological changes and globalization, today's youth has become aware of unpredictable times. Most do not identify themselves with the label "lost generation", "generation in crisis" or any other label that indicates an inferiority complex. Instead, most young people are now ready to create their own future, but they still demand from their families, communities, institutions and governments to empower them and ensure that they are best prepared for growing up in an environment that supports their aspirations and potentials.

During 2012, within the International Labor Conference (ILC) in June 2012, representatives of governments, employers' organizations and trade unions of 185 ILO member states adopted a call for action on youth employment called "Call for Action", (ILO, 2015). The urgency of Call for Action in response to the unprecedented global youth employment crisis did not reduce unemployment, despite some current signs of recovery in the markets of developed economies. "Call for action" gained both importance and scope.

\section{METHODOLOGICAL ASSUMPTIONS}

The research "Analysis of attitudes and opinions of young people in connection with starting their own business and implementation of socially responsible business" is realized within the project "Improvement of entrepreneurial climate, analysis of aspects and possible directions for youth action in Central Banat District", financed by the Autonomous Province of Vojvodina. The aims of this research determined the attitudes and opinions of the respondents about starting their own business, that is, the success of business practice in companies in the target region as well as in Serbia. It was scheduled to conduct the examination by the direct structured interview technique. The planned research sample consisted of a total of 350 respondents - 300 active students and 50 respondents of the appropriate age group, who completed their studies, as a control group.
200 students of the Technical Faculty "Mihajlo Pupin" and 100 students from the Technical College of Applied Sciences - both institutions from Zrenjanin - were examined. The control group consisted of respondents who are currently unemployed and one part of the respondents (about a half), thanks to the support of local SMEs, were employed by enterprises. The survey was carried out by using an anonymous, structured questionnaire.

The results of previous research covering the territory of Serbia were published on several occasions, for example: Ććckalo et al. (2013), Bogetić et al. (2014) and Ćoćkalo et al. (2015). The questions the research was based on, to which an answer will be asked below, are:

- What are the arguments for and against entrepreneurship?

- What sort of business environment for starting and running a business do the respondents anticipate?

- How do the respondents experience the financial aspect of the business environment in Serbia?

- Optionally: Are there any noticeable differences in the attitudes and opinions between the respondents of the basic and control groups and what are they?

\section{ANALYSIS OF THE RESEARCH RESULTS}

Figure 3 shows the ratio of the number of unemployed in Serbia and Vojvodina, as well as the movement of the unemployment rate in relation to the active population in the period from 20102016 in Serbia, Vojvodina and the Central Banat District.

Measures that, among other things, imply that the population situation in order to change, in the function of creating new jobs, can go in the direction of encouraging the development of small and medium-sized enterprises (SMEs), that is, towards self-employment. The creation of the environment and incentive measures, in line with and customized by the local community, in this direction, are the key factors for further analysis.

\section{Arguments "for and against" entrepreneurship}

The research has shown that the vast majority of respondents have a very affirmative look on private business, as well as starting and running a 
business. The almost identical percentage of young people has the desire to start their own business: the basic group - $79.73 \%$, the control group - $80 \%$. Private business is for respondents "risk and uncertainty" (basic group - 22.34\%, control group $17.7 \%$ ), as well as a "challenge" (basic group - $30.76 \%$, control group - 30.97\%). The control group sees private business as "satisfaction and self-expression" (22.12\%). They agree (the basic group - $45.51 \%$, the control group - $22 \%$ ) or mostly agree (the basic group - $35.55 \%$, the control group - 56\%) when asked "Do you think that people do not know the real business opportunities of private companies yet? " They mostly agree (the basic group - $48.66 \%$, the control group - 55.1\%) when asked "Do you think that private business is more successful than doing business in other forms of ownership?".

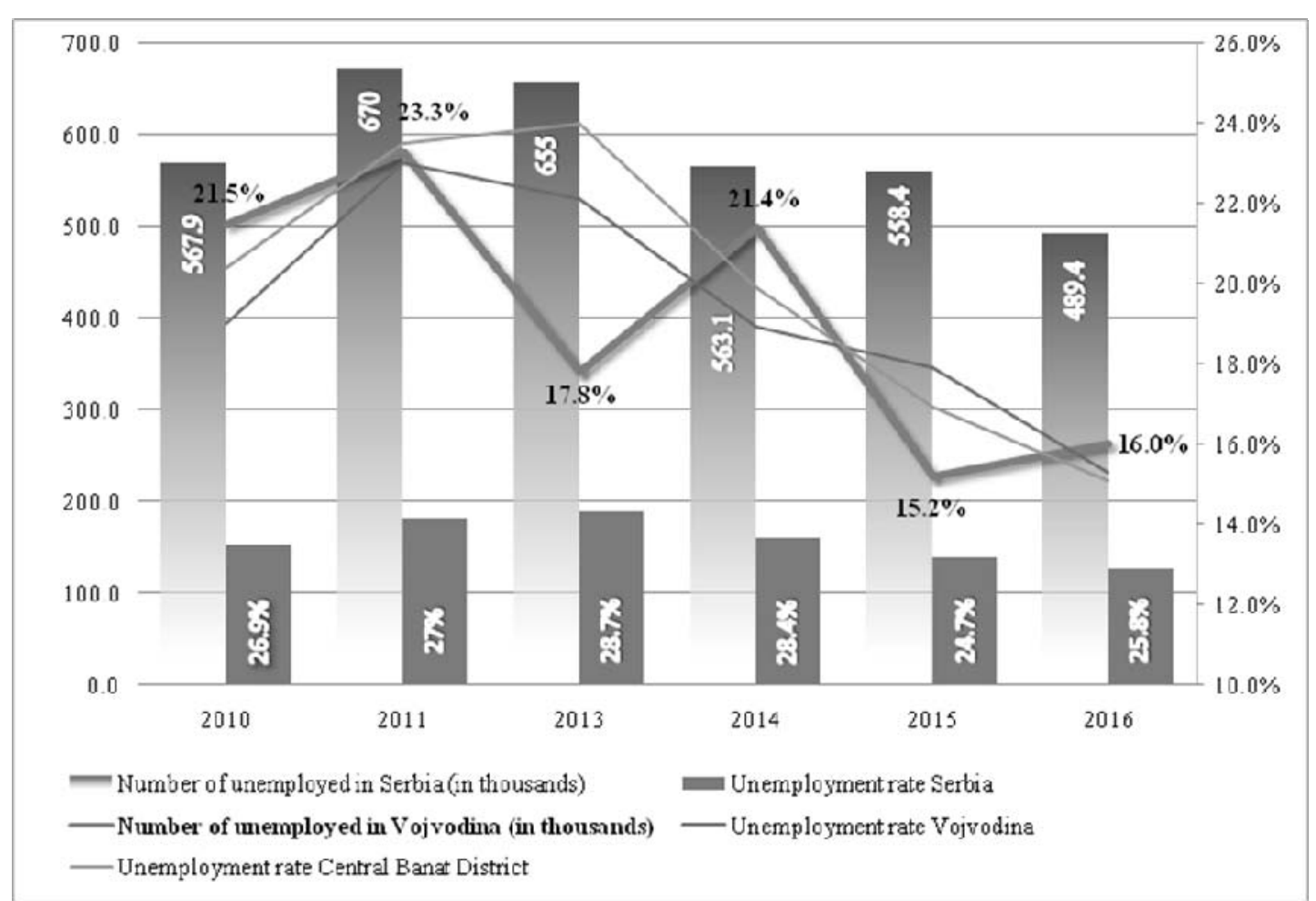

Figure 3: Ratio of the number of unemployed in Serbia and Vojvodina; Unemployment rate in the Central Banat District in relation to the active population Source: SORS, 2017.

Among the main reasons for not starting their own business stated by the respondents who say that they would not start it, are two reasons that were singled out: insufficient financial resources and insecure political and economic situation. As the third reason for the basic group, the reason "I do not have the right idea" has been stated - Table 3 Nearly $6 \%$ of the total number of respondents in the control group is not interested in dealing with private businesses.

Table 3: The most important reasons for not starting their own business

\begin{tabular}{|l|c|c|}
\hline & Basic group & Control group \\
\hline Insufficient financial resources & $19.4 \%$ & $35.7 \%$ \\
\hline Insecure political and economic situation & $19.4 \%$ & $21.4 \%$ \\
\hline I do not have the right idea & $23.1 \%$ & $0 \%$ \\
\hline I do not have the experience & $13.4 \%$ & $7.1 \%$ \\
\hline Lack of good associates to start business with & $9.7 \%$ & $7.1 \%$ \\
\hline I do not have enough knowledge & $8.21 \%$ & $0 \%$ \\
\hline I am not interested & $1.94 \%$ & $28.6 \%$ \\
\hline
\end{tabular}

Lack of knowledge among respondents is one of the factors that is indirectly related to other factors that hinder their desire to start their own business. As a result of a lack of knowledge, young people 
do not have the right ideas, or they do not have enough self-confidence and do not believe in themselves to be able to manage their own company, which in the end can lead to lack of interest in starting their own business. Figure 4 shows which specific knowledge the respondents most frequently cite, as well as the deviations that exist on this issue.

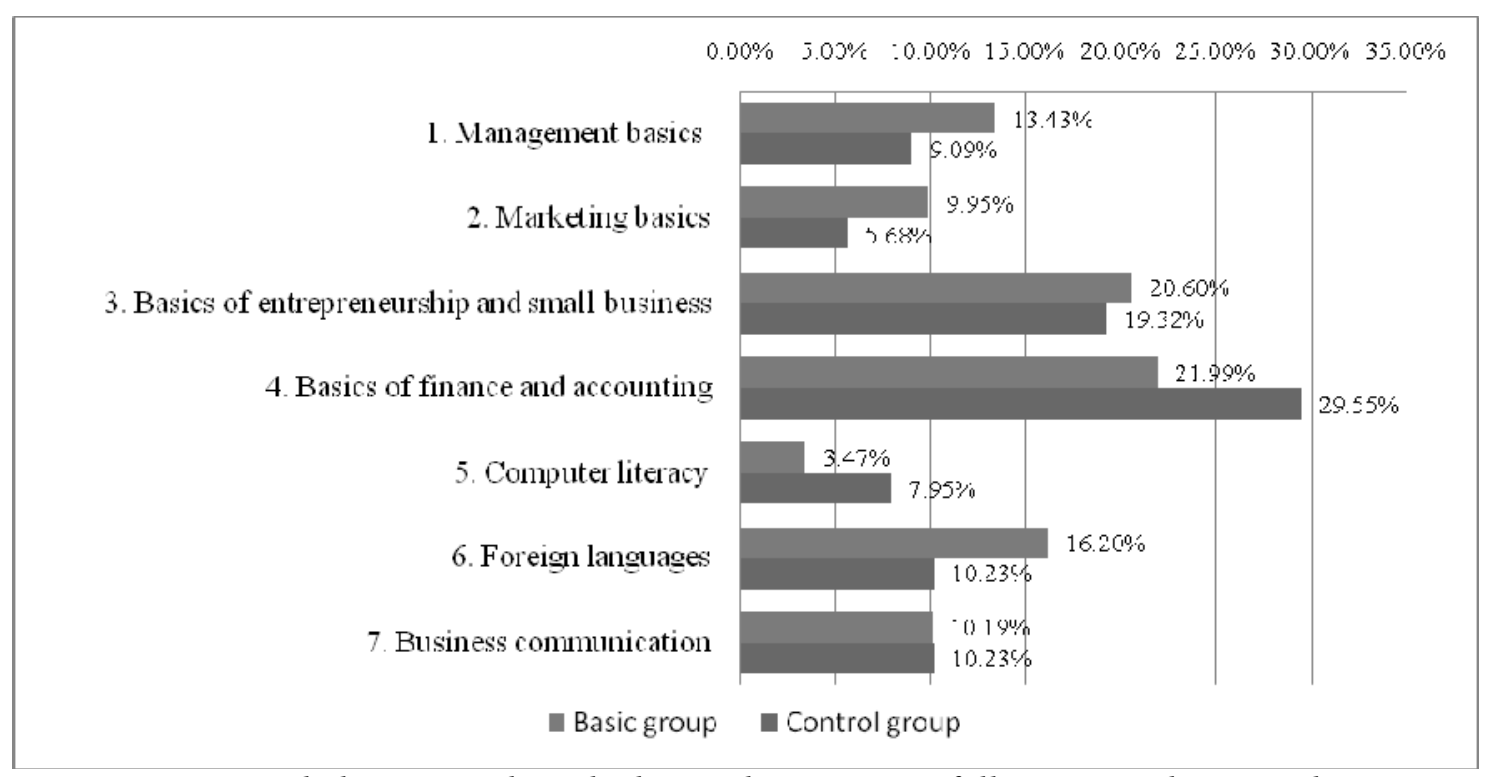

Figure 4: Knowledge respondents lack in order to successfully manage their own business

The research has shown that the basics of finance and accounting, or entrepreneurship and small businesses, take up an important position as required knowledge - on average, close to $50 \%$ of all respondents cite these answers. Foreign languages are the third category of knowledge that the basic group of respondents lack. Significant correlations in respondents' answers are present with: the basics of entrepreneurship and small business, the basics of business communication. Significant deviations in responses occur in the basics of finances and accounting (dominantly among the control group) and in foreign languages (dominantly among the basic group).

\section{Entrepreneurial environment}

When it comes to the environment for starting their own business, young people, at the level of the total sample, mostly (the basic group - $83.33 \%$, the control group - 74\%) believe that it is not suitable and that the state must be the key driver in this process (basic group - 89.3\%, control group $96 \%)$.
Out of possible answers to the question "Indicate what are the biggest restrictions for starting your own business", viewed on the level of the whole sample, three answers were highlighted: unstable political and economic situation, lack of financial resources and excessive taxes - Figure 5.

The data in Figure 6 shows more precisely what the necessary incentives are for young people to start their own business. Three key measures are emphasized to support young people: more favorable loans, education and laws / regulations related to youth as entrepreneurs.

The abovementioned should also be the starting point for state institutions, as well as local selfgovernment institutions dealing with economic and youth issues, in order to find solutions and create an environment for encouraging young people to take up entrepreneurship and start their own business. 


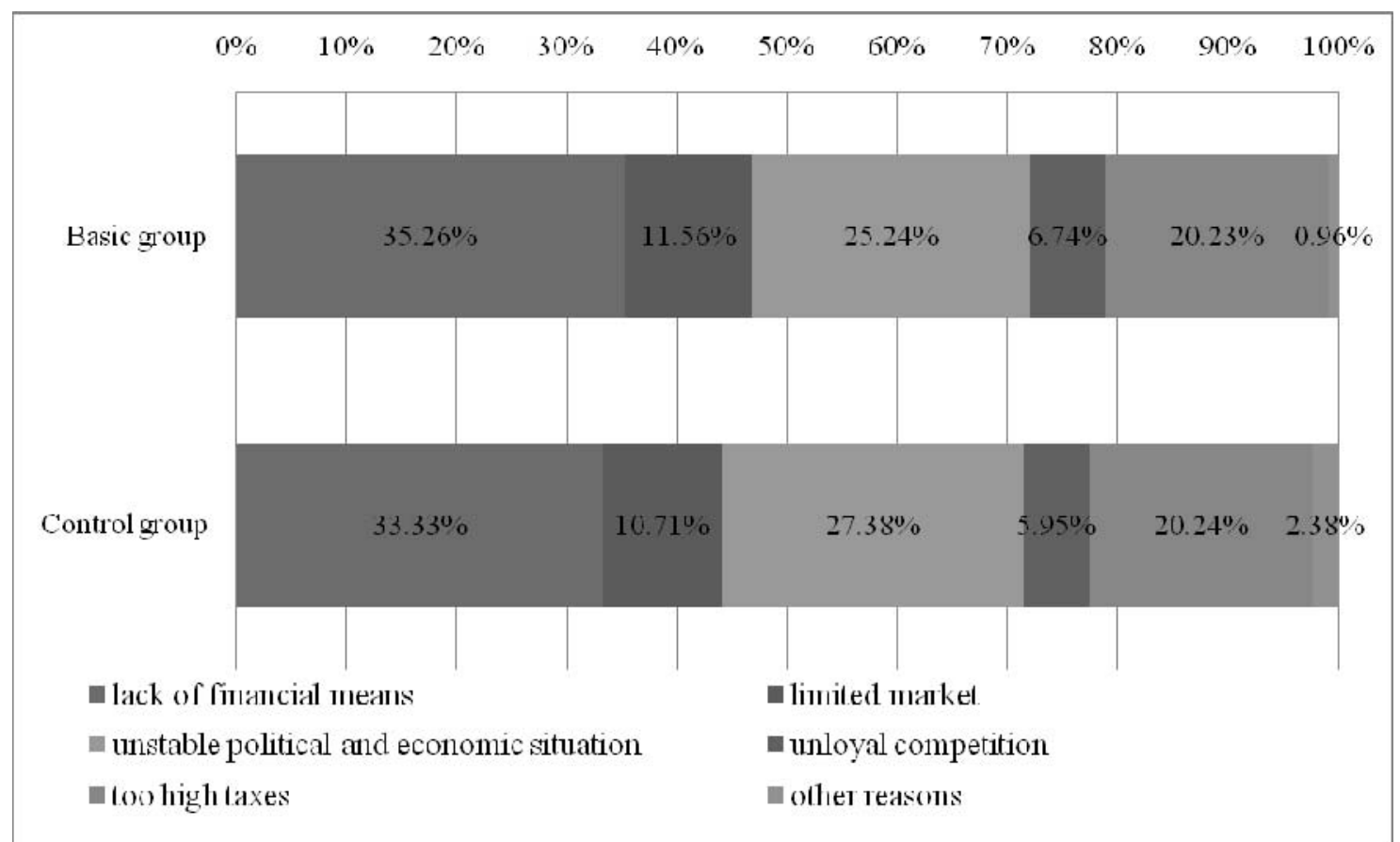

Figure 5: Biggest restrictions for self-employment

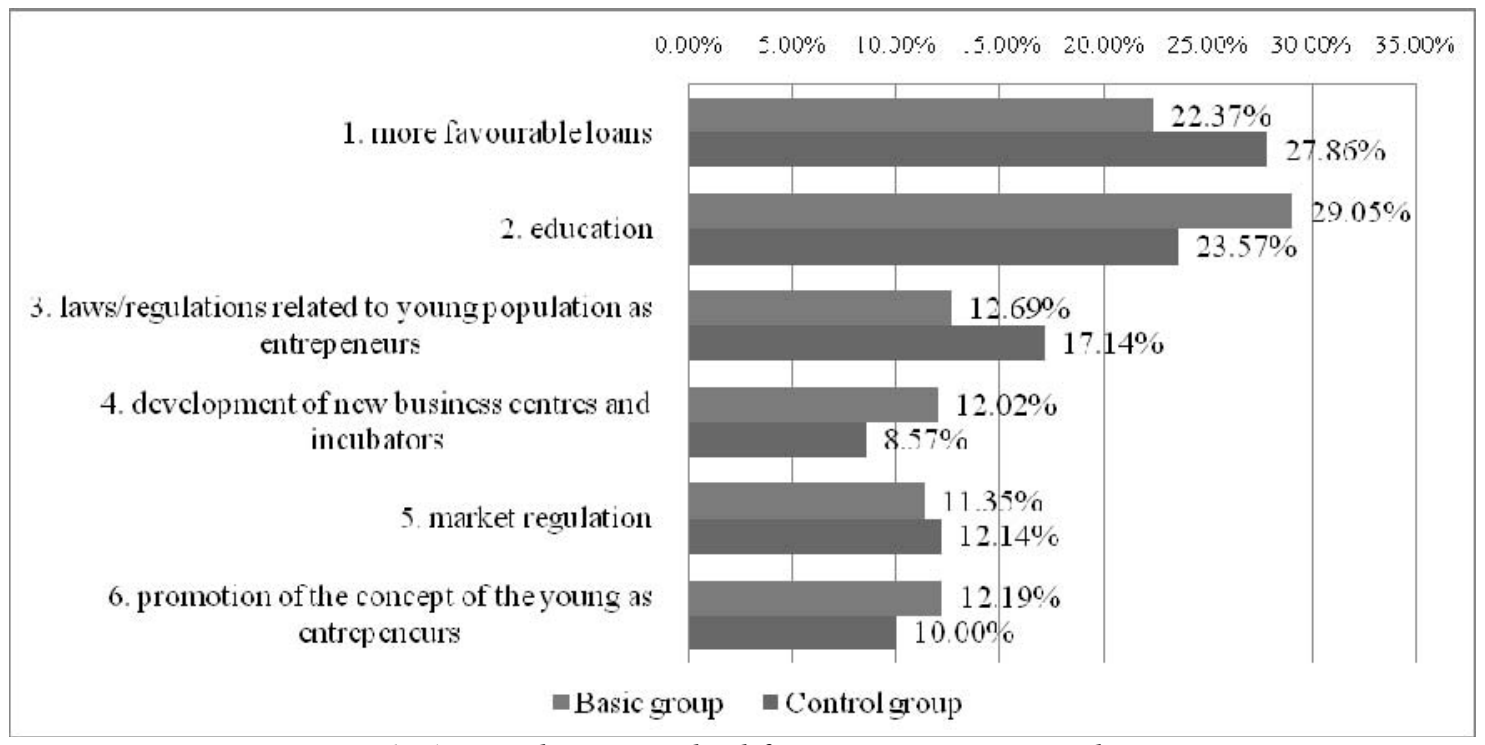

Figure 6: A stimulation method for starting your own business

\section{Business Finances}

When it comes to the environment for starting their own business, young people, at the level of the total sample, mostly (the basic group - $83.33 \%$, the control group - 74\%) believe that it is not suitable and that the state must be the key driver in this process (basic group - $89.3 \%$, control group $96 \%)$.

The problem of financial support for young entrepreneurs, that is, start-up loans, is something that the professional public, as well as the entrepreneurs themselves, refers to as a serious problem for both potential and existing entrepreneurs.

The survey showed that the respondents mostly turn to financing from their own resources (the basic group - $64.12 \%$, the control group - 53.70\%). Of the four possible forms of lending, respondents are least interested in loans from banks. They are accompanied by mutual funds and state resources, where the basic group gives priority to the first, and the control group to other type of funds. The reason for such a relationship can be found in the lack of confidence of young people in the banking 
system, that is, the credit policy of banks towards the economy - Figure 7.

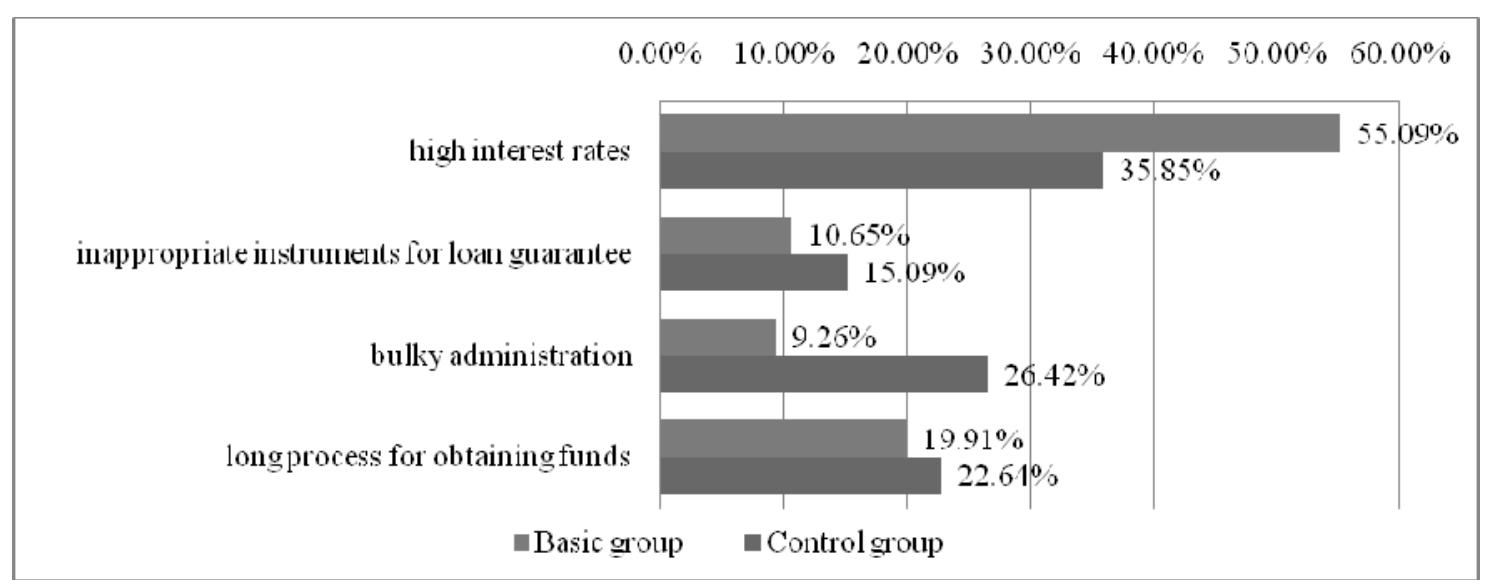

Figure 7: Reasons why start-up bank loans unfavorable for young entrepreneurs

The key problem arises here - at the moment there is not enough credit line on the domestic market to start a business, i.e. start-up loans, which help young entrepreneurs.

Quite understandably, the results show that respondents of the basic group are not well informed about the existence of incentives to start their own businesses that are offered $(59.87 \%$ of those are uninformed), while the control group respondents are better informed $(60 \%$ of those informed). In line with the results, indecisiveness is present when ti comes to the question "Would you be the beneficiary of these funds?" - in the basic groups, $053.1 \%$ of the respondents are against, and in the control group the ratio is 50 $50 \%$.

\section{CONCLUSIONS}

Statistical indicators indicate an increase in youth unemployment, which is a serious global problem. The solution is to encourage entrepreneurial behavior among young people in order to train them to run their own business. Although this idea in some developed countries already exists, the only novelty is the improvement of the environment that will encourage young people to start their own business. The most important directions of action in the function of the development of the entrepreneurial economy are: to limit the operations of the bureaucratic apparatus, to create equal business conditions for all, to establish an entrepreneurial climate at the level of the economy. The future belongs to companies that will be the most imaginative, most innovative and flexible. The global economic crisis has shown that these are companies from the newly industrialized countries, such as China, India, Russia and Brazil. These countries had problems in the economic sphere, but they managed to overcome them. The key to their success was the optimization of the relationship between price and product quality, based on productivity. In the years to come, the main focus of business people around the world, especially in developed countries, will be to "do more with less."

Youth employment is now the highest policy priority in most countries in all regions, and has been introduced internationally as the development of a global youth employment strategy and is embedded in the development agenda of 2030, (ILO, 2015). With the growing number of statelevel initiatives involving many stakeholders and institutions from the public and private sectors, the focus now is on creating partnerships for policy coherence and effective coordination of youth employment.

Policy measures could be categorized by the kind of support offered to young people, in line with specific barriers to youth entrepreneurship and the market failures they deal with. They include:

- measures that provide financial support in various forms (for example: grants, one-time subsidies, loans, conversions of unemployment benefits in cash reliefs or exemptions and reduction of tax contributions and social security);

- "soft" support, including training related to entrepreneurship, counseling and professional mentoring;

- a combination of financial incentives with complementary aid measures; 
- awareness-raising initiatives and various measures to support entrepreneurship related to the education system, especially youth-oriented;

- a range of support services by providing the necessary infrastructure for potential entrepreneurs, especially in innovative and high-tech sectors, (ILO, 2015).

The most suitable intervention for individual countries depends on the main barriers and constraints that exist in those countries, in the sense that there is no solution that suits everyone. Above all, it is necessary to introduce a customized approach that takes into account different economic, social and cultural situations.

The data collected in the survey were obtained from the population of management and business students, so it was expected that most respondents in this sample would like to start their own business.

Therefore, students tend to start their own business, but most often cite the lack of financial resources as reasons that discourage them from this, but also the lack of experience in running the company, the lack of knowledge, and the lack of the right idea.

The obtained results also point to the fact that the situation in Serbia is destimulating and that greater attention should be paid to creating conditions and encouraging entrepreneurship among the young population. All negative factors that discourage respondents from starting their own business are the result of the lack of an adequate environment for encouraging entrepreneurship among young people. The facts from the field indicate that most of the activities so far in this area were limited and short-lived, and were most often sponsored by international organizations (USAID, GiZ, etc.)

In global terms, the research results point to two groups of areas for finding solutions to the development of entrepreneurial behavior among young people in the function of promoting competitiveness, which are current for the region: (1) education and education system, and (2) institutional action.

1. Education and education system: It is necessary to establish a new model of thinking based on the skills and abilities of students and university students, as well as the creation of new educational programs. Entrepreneurship education has to start as soon as possible. It is necessary to improve the system of realization of professional practice, both at faculties and secondary schools. The dual education system must be broadly represented in secondary schools.

2. Institutional action: It is necessary to motivate employers in the direction of more adequate realization of the professional practice and youth employment - the dominant aspect of motivation seems to be through tax deductions. It is necessary to adjust the local economic environment in terms of supporting the process of entrepreneurship development among young people. It is necessary to define the organizations that will deal with this process the absence of "connecting links" is found on the relation: educational institutions - labor market - students / university students / interested in starting a business.

\section{ACKNOWLEDGEMENT}

This paper has been supported by the Provincial Secretariat for Higher Education and Scientific Research of the Autonomous Province of Vojvodina, number: 142-451- 2502/2017-03.

\section{REFERENCES}

Abbey, A. (2002). Cross-cultural comparison of the motivation for entrepreneurship. Journal of Business and Entrepreneurship, 14(1), 69.

Bell, D. N. F., \& Blanchflower, D. G. (2011). Young people and the Great Recession. Oxford Review of Economic Policy, 27(2), 241-267.

Bogetić, S., Đorđević, D., \& Ćoćkalo, D. (2014). Attitude of Young People in Republic of Serbia in Reltion to Starting Own Business - Regional Aspect. Ekonomski vidici, 19(2-3), 303-312.

Ćoćkalo, D., Đorđević, D., Bešić, C., \& Bogetić, S. (2015). Undergraduate Business Students' Attitudes Towards CSR and Competitiveness of Serbian Economy. Journal of Engineering Management and Competitiveness (JEMC), 5(1), 12-20. doi: $10.5937 /$ jemc $1501012 \mathrm{C}$

Ćoćkalo, D., Đorđević, D., Bogetić, S., Sajfert, D., \& Minovski, R. (2013). Quality of Business, Entrepreneurship Education and Business Start-up Intentions among Students in Serbia: Research Results. Industrija, 41(3), 125-145. doi: 10.5937/industrija41-3889

Eurofound. (2014). Mapping youth transitions in Europe. Luxembourg: Publications Office of the European Union.

Eurofound. (2016). Start-up support for young people in the EU: From implementation to evaluation. 
Luxembourg: Publications Office of the European Union.

European Commission. (2012). Entrepreneurship in the EU and beyond, Flash Eurobarometer 354.

Brussels: Directorate-General Enterprise and Industry.

European Commission. (2014), Programming Period 2014-2020. Guidance document on monitoring and evaluation: European Cohesion Fund and European Regional Development Fund. Concepts and recommendations. Brussels

Eurostat. Unemployment rate by age. Retrieved 17.11.2017, from Eurostat

http://ec.europa.eu/eurostat/tgm/refreshTableAction. do? tab $=$ table\&plugin $=1 \&$ pcode $=$ tepsr_wc $170 \&$ lang uage $=$ en

Franco, M., Haase, H., \& Lautenschläger, A. (2010). Students' entrepreneurial intentions: an interregional comparison. Education+ Training, 52(4), 260-275. doi: 10.1108/00400911011050945

ILO. (2012). The youth employment crisis: Time for action, Report V, International Labour Conference, 101st Session. Geneva: ILO.

ILO. (2015). Global Employment Trends for Youth 2015: Scaling up investments in decent jobs for youth. Geneva: International Labour Office.

Kew, J., Herrington, M., Litovsky, Y., \& Gale, H. (2013). Generation Entrepreneur? The state of global youth entrepreneurship. Cape Town, South Africa: Global Entrepreneurship Research Association / Youth Business International.
McKenzie, B., Ugbah, S. D., \& Smothers, N. (2007). "Who Is an Entrepreneur?" Is It Still the Wrong Question?. Academy of Entrepreneurship Journal, 13(1), 23-43.

Phororo, H. (2013). Rethinking Youth Employment Coordination in East Africa. Dar es Salaam, Tanzania: ILO Office.

Schoof, U. (2006). Stimulating youth entrepreneurship: Barriers and incentives to enterprise start-ups by young people, SEED Working Paper, No. 76. Geneva: International Labour Organization.

SORS. (2017). Labour Force Survey. Retrieved 17.11.2017, from Statistical Office of the Republic of Serbia http://www.stat.gov.rs

Strandh, M., Winefield, A., Nilsson, K. and Hammarstrom, A. (2014). Mental health scarring during the life course. European Journal of Public Health, 24(3),440-445. doi: 10.1093/eurpub/cku005

Thompson, E. R. (2009). Individual entrepreneurial intent: Construct clarification and development of an internationally reliable metric. Entrepreneurship Theory and Practice, 33(3), 669-694. doi: 10.1111/j.1540-6520.2009.00321.x

$\mathrm{UN}$. (2014). A concise report on the world population situation in 2014. New York: Department of Economic and Social Affairs.

Wilson, F., Kickul, J., \& Marlino, D. (2007). Gender, entrepreneurial Self-Efficacy, and entrepreneurial career intentions: Implications for entrepreneurship Education1. Entrepreneurship theory and practice, 31(3), 387-406. doi: 10.1111/j.15406520.2007.00179.x

\title{
ANALIZA MOGUĆNOSTI ZA UNAPREĐENJE PREDUZETNIČKOG PONAŠANJA KOD MLADIH - REZULTATI ISTRAŽIVANJA REGIONA SREDNJEG BANAT
}

\begin{abstract}
Nezaposlenost, posebno kod mlade populacije, predstavlja jedan od ključnih ekonomskih problema. U prevazilaženju ovih problema moraju da se uključe sve relevatne institucije, u cilju stimulisanja mladih ka uključivanju u preduzetničke procese. U radu su prikazani globalni, evropski i trendovi u regiona Zapsadnog Balkana, a tiču se nezaposlenosti kod mlade (15-24 godine) poopulacije. Centralni deo posvećen je analiza mogućnosti za unapređenje preduzetnickog ponašanja kod mladih u regionu Srednjeg Banata, a na bazi trendova, statističkih pokazatelja i rezultata sprovedenog istraživanja stavova mladih prema preduzetništvu i pokretanju sopstvenog biznisa. Uzorak istraživanja sprovedenog 2016. je sačinjavalo 350 ispitanika. Mladi su nestimulisani za uključivanje u preduzetničke procese - imaju želju da osnuju sopstveni biznis, ali kao najčešće kao razloge koji ih od toga odvraćaju navode: nedostatak finansijskih sredstava, nedostatak iskustva u vođenju preduzeća, nedostatak znanja, kao i nedostatak prave ideje. Faktori koji odvraćaju ispitanike da pokrenu sopstveni biznis, predstavlju rezultat nepostojanja adekvatnog ambijenta za podsticanje preduzetništva kod mladih.
\end{abstract}

Ključne reči: Nezaposlenost, Preduzetništvo, Mladi kao preduzetnici, Samozapošljavanje, Regionalni razvoj. 